\title{
FAKTOR-FAKTOR YANG MEMPENGARUHI PRAKTIK PEMBERANTASAN SARANG NYAMUK (PSN) DI LINGKUNGAN TANJUNG REJO MEDAN SUNGGAL
}

\author{
Astuti Rofida ${ }^{1}$, Resmi Pangaribuan ${ }^{2}$, Khairunnisa Batubara ${ }^{3}$ \\ Akademi Keperawatan Kesdam I/BB Medan \\ rofidaastuti86@gmail.com ${ }^{1}$, resmipangaribuan131417@gmail.com ${ }^{2}$
}

\begin{abstract}
Dengue Hemorrhagic Fever is a viral disease carried by mosquitoes and usually occurs in tropical and subtropical areas. Symptoms can include fever, rash, and muscle and joint pain. Handling can be done by giving adequate fluids and pain relievers. One of the most appropriate efforts in preventing and eradicating mosquitoes is by eradicating mosquito nests. The purpose of this study was to determine the factors that influence the practice of eradicating mosquito nests in Tanjung Rejo Village, Medan Sunggal District. The purpose of this study was to determine the factors that influence the practice of eradicating mosquito nests in the Tanjung Rejo Village, Medan Sunggal District. This type of research is Explantory Research with research population of 451 people and the number of samples is 82 people. This research instrument using a questionnaire with analysis using the chi-sguare statistical test with a degree of significance $(\alpha)=0.01$. The results showed that there was a relationship between knowledge $(p=0.000)$, attitude $(p=0.000)$ education $(p=0.275)$, occupation $(p=0.572)$, support from health workers $(p=0.000)$, and family support $(p=$ $0.000)$, the results of the multivariate show that the p-value is $0.00<0.01$ then there is an influence on the practice of eradicating mosquito nests in the Tanjung Rejo environment, Medan Sunggal. Suggestions for the community to further improve the practice of eradicating dengue mosquito nests, and for health workers to send information continuously and continuously.
\end{abstract}

Keywords : Eradication of Mosquito Nests, Knowledge and Attitudes, Dengue heart fever support from families and health workers.

\begin{abstract}
ABSTRAK
Dengue Hemorrhagic Fever merupakan Penyakit virus yang dibawa oleh nyamuk dan biasanya terjadi di daerah tropis dan subtropis. Gejala yang ditimbulkannya dapat demam, ruam, serta nyeri otot dan sendi. Penanganan dapat dilakukan dengan pemberian cairan yang cukup dan pereda nyeri. Salah satu upaya yang paling tepat dalam pencegahan dan pemeberantasan nyamuk adalah dengan kegiatan pemberantasan sarang nyamuk. Tujuan dari penelitian ini adalah untuk mengetahui faktor-faktor yang mempengaruhi praktik pemberantasan sarang nyamuk di Lingkungan Desa Tanjung Rejo Kecamatan Medan Sunggal. Jenis penelitian ini adalah Explantory Research dengan popolasi penelitian 451 orang dan jumlah sampel adalah 82 orang. Instrumen penelitian ini dengan menggunakan kuesioner dengan analisis menggunakan uji statistic chi-sguare dengan derajat kemaknaan $(\alpha)=0,01$. Penelitian diketahui diketehui bahwa ada hubungan antara pengetahuan $(p=0,000)$, sikap $(\mathrm{p}=0,000)$ pendidikan $(\mathrm{p}=0,275)$, pekerjaan $(\mathrm{p}=0,572)$, dukungan petugas kesehatan $(\mathrm{p}=0,000)$, dan dukungan keluarga $(\mathrm{p}=0,000)$, hasil dari multivariate diketahui bahwa bahwa p-value $0,00<0,01$ maka ada pengaruh Praktik Pemberantasan Sarang Nyamuk Di Lingkungan Tanjung Rejo Medan Sunggal. Kesimpulan: ada pengaruh Praktik Pemberantasan Sarang Nyamuk Di Lingkungan Tanjung Rejo Medan Sunggal. Saran bagi masyarakat hendaknya
\end{abstract}


lebih meningkatkan Praktik Pemberantasan Sarang Nyamuk DBD, dan bagi petugas kesehatan dapat menyampaikan informasi secara berkesinambungan dan terusmenerus.

Kata Kunci : Pemberantasan Sarang Nyamuk, Pengetahuan Dan Sikap, Dengue Heart Fever Dukungan Keluarga Dan Petugas Kesehatan.

\section{PENDAHULUAN}

Penyakit Dengue Hemorrhagic Fever atau demam berdarah dengue (DBD) sampai saat ini salah satu masalah kesehatan masyarakat Indonesia dan cenderung meningkat. Demam berdarah merupakan penyakit yang di sebabkan oleh virus dengue dan ditularkan melalui nyamuk terutama Aedes Agepty dan Aedes Albopictus yang ditemukan di daerah tropis dan subtropics diantaranya kepulauan Indonesia hingga bagian Australia. Keempat virus dengue menginfeksi manusia di daerah Afrika dan Asia tenggara sejak 100-800 tahun yang lalu. Virus dengue berkembang pesat pada perang dunia ke-2 dimana penyebarannya terjadi secara missal dengan pengiriman barang yang berperan dalam penyebaran global DBD (Maranatha, 2013).

Saat ini Kasus DBD tersebar di 472 kabupaten/kota di 34 Provinsi. Kematian Akibat DBD terjadi di 219 kabupaten/kota. Kasus DBD sampai dengan Minggu Ke-49 sebanyak 95.893, sementara jumlah kematian akibat DBD sampai dengan Minggu Ke 49 sebanyak 661. Info terkini DBD tanggal 30 November 2020 ada 51 penambahan kasus DBD dan 1 penambahan kematian akibat DBD. sebanyak 73,35\% atau 377 kabupaten/kota sudah mencapai Incident Rate (IR) kurang dari 49/100.000 penduduk. Proporsi DBD Per Golongan Umur antara lain $<1$ tahun sebanyak $3,13 \%, 1-4$ tahun: $14,88 \%, 5$ - 14 tahun $33,97 \%, 15-44$ tahun 37,45 $\%,>44$ tahun $11,57 \%$. Adapun proporsi Kematian DBD Per Golongan Umur antara lain < 1 tahun, 10,32\%, $1-4$ tahun 28,57 $\%, 5-14$ tahun $34,13 \%, 15-44$ tahun : $15,87 \%$. > 44 tahun $11,11 \%$. Di Indonesia DBD menyerang laki-laki sebanyak $53,11 \%$ dan perempuan sebanyak 46,89\% (Kementerian Kesehatan RI, 2020).

Perilaku masyarakat dalam pencegahan penyakit DBD dilakukan di wilayah kerja Puskesmas Medan Sunggal sebagai wilayah kerja Puskesmas tersebut yang setiap tahun terjadi kasus DBD (merupakan salah satu kecamatan yang endemis DBD).

Berdasarkan data surveilens dari Dinas Kesehatan Kota Medan pada tahun 2014 terdapat 1.699 kasus DBD dengan jumlah kematian 15 orang, incidence rate $(I R)=77,5$ per 100.000 penduduk. Pada tahun 2018, Provinsi Sumatera Utara menempati posisi ketiga dengan kasus DBD tertinggi di Indonesia, jumlah kasus DBD sebanyak 5.623 kasus (IR 39,01 per 100.000). Jumlah kasus meninggal sebanyak 26 orang (CFR 0,46\%). Kabupaten yang terjangkit DBD pada tahun 2018 sebanyak 32 kabupaten dari 33 kabupaten di Provinsi Sumatera Utara (Kemenkes RI, 2018). Jumlah kasus tertinggi terdapat di Kecamatan Medan Sunggal yaitu 171 kasus (Dinas Kesehatan Kota Medan, 2015).

Program Pemberantasan Sarang Nyamuk (PSN) 3M Plus berisi kegiatankegiatan, diantaranya menguras tempat penampungan air, menutup rapat tempat penampungan air, mengubur dan menyingkirkan barang bekas, memantau keberadaan jentik, dan pengelolaan lingkungan berlanjut seperti meningkatkan kesadaran terhadap kebersihan lingkungan untuk menurunkan potensi tempat perkembangbiakan nyamuk (Respati et al., 2016). Hal itu dapat menurunkan kasus DBD. Kebiasaan menggantung pakaian dapat menyebabkan jumlah nyamuk di dalam rumah bertambah karena seringkali 
nyamuk lebih senang hinggap pada pakaian yang menggantung (Ardha dinata, 2011).

Pada penelitian Rahmadani (2017) tidak terdapat variabel kinerja kader jumantik, sedangkan dalam penelitian ini variabel kinerja kader jumantik diteliti untuk mengetahui faktor risiko dengan kejadian DBD di wilayah kerja Puskesmas Wonokarto. Kinerja kader jumantik perlu diteliti hal ini dikarenakan keaktifan kader di masyarakat dapat memotivasi masyarakat dalam melaksanakan PSN DBD sebagai upaya pencegahan demam berdarah. Berdasarkan uraian di atas peneliti bertujuan untuk mengetahui tentang faktor-faktor Praktik Pemberantasan Sarang Nyamuk DBD di Lingkungan Tanjung Rejo Medan Sunggal.

\section{METODE}

Penelitian ini menggunakan jenis penelitian survey dengan pendekatan Explanatory Research, yang bertujuan untuk menjelaskan pengaruh faktor predisposisi (pengetahuan dan sikap) dan faktor pendukung (dukungan petugas kesehatan dan dukungan keluarga) terhadap pemberantasan sarang nyamuk di Lingkungan Tanjung Rejo Medan Sunggal.

Populasi dalam penelitian ini adalah 451 orang dengan sampel berjumlah 82 orang

Tehnik pengambilan sampel dilakukan secara purposive sampling.

Metode Pengumpulan data dengan Uji Validitas (Instrument uji validitas menggunakan uji korelasi product moment person dengan $\alpha=1 \%$ ), Uji Reliabilitas (product moment $\alpha=1 \%$ ) menggunakan SPSS. Analisis data kuantitatif dilakukan dengan menggunakan program statistik (statistic/data analysis) adalah Analisis Univariat, bivariat dan multivariate.
HASIL

Tabel 1. Distribusi frekuensi kategori pengetahuan responden terhadap PSN dikelurahan Desa Tanjung Rejo

\begin{tabular}{llll}
\hline No & $\begin{array}{l}\text { Pengetahuan } \\
\text { responden }\end{array}$ & Jumlah & \\
\hline & & $\mathrm{F}$ & $\%$ \\
\hline 1 & Tahu & 43 & 52,4 \\
\hline 2 & Tidak tahu & 39 & 47,5 \\
\hline & Total & 82 & 100 \\
\hline
\end{tabular}

Dari tabel diatas dapat disimpulkan bahwa mayoritas pengetahuan responden tentang PSN di Kelurahan Tanjung Rejo adalah tahu $(52,4 \%)$.

Tabel 2. Distribusi frekuensi kategori sikap responden terhadap PSN dikelurahan Desa Tanjung Rejo

\begin{tabular}{llll}
\hline No & Sikap responden & Jumlah & \\
& & F & $\%$ \\
\hline 1 & Baik & 46 & 56,1 \\
\hline 2 & Kurang baik & 36 & 43,9 \\
\hline & Total & 82 & 100 \\
\hline
\end{tabular}

Dari tabel diatas dapat disimpulkan bahwa mayoritas sikap responden tentang PSN di Kelurahan Tanjung Rejo adalah baik $(56,1)$.

Tabel 3. Distribusi frekuensi kategori pendidikan responden terhadap PSN dikelurahan Desa Tanjung Rejo

\begin{tabular}{llll}
\hline No & $\begin{array}{l}\text { Pendidikan } \\
\text { responden }\end{array}$ & Jumlah \\
\hline & R & $\%$ \\
\hline 1 & Rendah & 23 & 28,0 \\
\hline 2 & Menengah & 25 & 30,5 \\
\hline 3 & Tinggi & 34 & 41,5 \\
\hline 4 & Total & 82 & 100 \\
\hline
\end{tabular}

Dari tabel dapat disimpulkan bahwa mayoritas pendidikan responden tentang PSN di Kelurahan Tanjung Rejo adalah tinggi $(41,5 \%)$.

Dari tabel 4 dapat disimpulkan bahwa Dukungan petugas kesehatan tentang PSN di Kelurahan Tanjung Rejo adalah mendukung $(63,4 \%)$ 
Tabel 4 Distribusi frekuensi kategori dukungan petugas kesehatan terhadap PSN dikelurahan Desa Tanjung Rejo

\begin{tabular}{llll}
\hline No & $\begin{array}{l}\text { Dukungan petugas } \\
\text { kesehatan }\end{array}$ & Jumlah & \\
\hline & & $\mathrm{f}$ & $\%$ \\
\hline 1 & Mendukung & 52 & 63,4 \\
\hline 2 & Tidak mendukung & 30 & 36,6 \\
\hline & Total & 82 & 100 \\
\hline
\end{tabular}

Tabel 5. Distribusi frekuensi kategori dukungan keluarga terhadap PSN dikelurahan Desa Tanjung Rejo

\begin{tabular}{llll}
\hline No & Dukungan keluarga & Jumlah & \\
\hline & & $\mathrm{f}$ & $\%$ \\
\hline 1 & Mendukung & 44 & 53,6 \\
\hline 2 & Tidak mendukung & 38 & 46,3 \\
\hline & Total & 82 & 100 \\
\hline
\end{tabular}

Dari tabel 5 dapat disimpulkan bahwa Dukungan keluarga tentang PSN di Kelurahan Tanjung Rejo adalah mendukung $(53,6 \%)$

Tabel 6. Distribusi frekuensi kategori pemberantasan sarang nyamuk dikelurahan Desa Tanjung Rejo

\begin{tabular}{llll}
\hline No & $\begin{array}{l}\text { Pemberantasan } \\
\text { sarang nyamuk }\end{array}$ & Jumlah & \\
\hline & & $\mathrm{f}$ & $\%$ \\
\hline 1 & Melakukan & 47 & 57,3 \\
\hline 2 & Tidak Melakukan & 35 & 42,7 \\
\hline & Total & 82 & 100 \\
\hline
\end{tabular}

Dari tabel diatas dapat disimpulkan bahwa pemberantasan sarang nyamuk di Kelurahan Tanjung Rejo adalah melakukan $(57,3 \%)$

Dan yang tidak melakukan sebanyak 35 $(42,7 \%)$

\section{PEMBAHASAN}

\section{Hubungan Pengetahuan terhadap praktik PSN}

Hasil penelitian menunjukkan bahwa dari 82 responden memiliki pengetahuan tentang PSN sebanyak 43 orang $(52,4 \%)$ yang melakukan praktik PSN sebanyak 43 orang $(52,4 \%)$ dan tidak melakukan praktek PSN sebanyak 0. Pada masyarakat yang tidak memiliki pengetahuan tentang PSN sebanyak 39 orang $(47,6 \%)$ yang melakukan praktik PSN sebanyak 4 orang $(4,8 \%)$ dan tidak melakukan praktik PSN ebanyak 35 orang $(42,7 \%)$. Hasil uji statistic dengan menggunakan uji chi-square, diperoleh hasil $\mathrm{p}$ value 0,000 , karena $\mathrm{p}$ value $<0,01$ maka Ha diterima maka ada hubungan antara pengetahuan ibu terhadap praktik PSN di kelurahan Tanjung Rejo Sunggal.

Pengetahuan baik dan kurang dapat dipengaruhi oleh beberapa faktor seperti sumber informasi baik dari lingkungan keluarga, tetangga, petugas kesehatan, maupun media cetak dan media elektronik (Nurhayati, 2014). Responden yang memiliki tingkat pengetahuan baik ternyata memang banyak yang melakukan paraktik PSN DBD dengan baik bila dibandingkan dengan responden yang memiliki tingkat pengetahuan kurang. Pada umumnya responden yang memiliki tingkat pengetahuan baik merasa takut akan penularan penyakit DBD, sehingga responden yang memiliki tingkat pengetahuan baik akan lebih tanggap dan rajin melaksanakan kegiatan PSN DBD.

Secara teoritis pengetahuan ada hubungan dengan PSN. Hasil penelitian ini sesuai dengan penelitian yang dilakukan oleh Nurhayati yang menyebutkan bahwa terdapat hubungan yang signifikan antara pengetahuan dengan praktik PSN DBD. Hasil penelitian ini sejalan dengan penelitian sebelumnya karena desain penelitian yang digunakan sama. Dalam penelitian tersebut menyatakan bahwa pengetahuan yang baik menjadi dasar bagi seseorang untuk bertingkah laku.

Menurut Asumsi Peneliti, Pengetahuan tentang cara melakukan PSN dan manfaat dari kegiatan PSN, sebagian responden sudah mengetahui dengan baik tentang bagaimana cara melakukan PSN dan manfaat yang diperoleh dari PSN, namun ada juga responden yang belum memahami bahwa PSN itu adalah 
tanggung jawab semua warga masyarakat. Masyarakat beranggapan bahwa PSN (fogging) merupakan tanggung jawab pemerintah dan masyarakat beranggapan bahwa pemerintah belum bekerja apabila tidak melaksanakan fogging tersebut.

\section{Hubungan sikap ibu terhadap praktik PSN}

Hasil penelitian menunjukkan dari 82 orang responden yang memiliki sikap mendukung tentang PSN sebanyak 46 orang $(65,1 \%)$ yang melakukan praktik sebanyak 44 orang $(53, \%)$ dan tidak melakukan praktik PSN sebanyak 2 orang $(2,4 \%)$. Pada masyarakat yang tidak mendukung sikap tentang PSN sebanyak 36 orang $(43,6 \%)$ yang melakukan PSN sebanyak 33 orang $(40,2 \%)$ Hasil uji statistik dengan menggunakan chi-square, diperoleh $p$ value 0,000. Karena p-value $<0,01$ maka $\mathrm{Ha}$ diterima maka ada hubungan antara sikap ibu terhadap penyakit pemberantasan sarang nyamuk di desa Tanjung Rejo Medan Sunggal.

Hasil penelitian ini sesuai dengan teori Gren yang menyatakan bahwa sikap adalah faktor yang berperan dalam perilaku kesehatan. Semakin positif dan baik wawasan seseorang terhadap sesuatu hal maka semakin baik pula tindakan yang dilakukan dalam hal tersebut.

Hasil penelitian ini sejalan dengan penelitian yang dilakukan oleh Nurhayati yang menyatakan bahwa terdapat hubungan bermakna antara sikap dengan praktik pemberantasan sarang nyamuk oleh masyarakat (Mohammad, 2015)

Namun hasil penelitian ini bertentangan dengan penelitian yang dilakukan oleh Hardayati yang menyatakan bahwa tidak ada hubungan antara sikap dengan praktik PSN DBD di Kecamatan Pekanbaru Kota Riau. Hasil penelitian berbeda karena penelitian dilakukan ditempat yang berbeda dengan respon yang berbeda dengan penelitian sebelumnya.
Menurut asumsi peneliti sikap merupakan reaksi atau respon yang masih tertutup dan seseorang terhadap suatu stimulus atau objek. Manifestasi sikap itu tidak bisa dilihat dengan langsung tetapi hanya dapat ditafsirkan terlebih dahulu dan perilaku yang tertutup. Sikap merupakan kesiapan uuntuk bereaksi terhadap objek di lingkungan tertentu sebagai suatu penghayatan terhadap objek.

\section{Hubungan Pendidikan ibu terhadap praktik PSN}

Hasil penelitian menunjukkan dari 82 orang responden yang memiliki pendidikan rendah sebanyak 23 orang $(28,1 \%)$ yang melakukan praktik PSN sebanyak 16 orang $(19,5 \%)$ dan tidak melakukan praktik PSN sebanyak 7 orang (8,5\%). Pada masyarakat yang memiliki pendidikan menengah sebanyak 25 orang $(30,4 \%)$ yang melakukan praktik PSN sebanyak 13 orang $(15,8 \%)$ dan tidak mellakukan PSN Sebanyak 12 orang $(14,6 \%)$. Hasil uji statistic dengan menggunakan chi-square diperoleh hasil p-value <0,01, maka Ha ditolak maka tidak ada hubunganantara pendidikan ibu terhadap praktik PSN di Kelurahan Tanjung Rejo kecamatan Sunggal. Hal ini tidak sesuai dengan pernyataan Notoadmodjoyang menyatakan bahwa seseorang yang memiliki tingkat pendidikan formal yang tinggi akan memiliki tingkat pengetahuan dan wawasan yang lebih baik dan luas serat memiliki sikap yang dewasa hal ini juga sesuai dengan penelitian yang dilakukan oleh Agustiansyah yang menyatakan bahwa tidak ada hubungan antara pendidikan dengan perilaku pemberantasan sarang nyamuk DBD. Hasil penelitain ini sejalan dengan penelitian sebelumnya karena terdapat kesamaan desain penelitian dan pengkategorian tingkat pendidikan responden.

Menurut asumsi peneliti, lamanya seseorang dalam menempuh pendidikan bukanlah jaminan untuk berperilaku 
sebagaimana yang diharapkan. Walaupun sebagian responden memiliki tingkat pendidikan yang rendah, tetapi mampu melakukan praktik PSN DBD dengan baik.

\section{Hubungan Pekerjaan terhadap praktik PSN}

Hasil penelitian menunjukkan dari 82 orang responden yang belerja dan melakukan PSN sebanyak 39 orang $(47,5 \%)$ dan tidak melakukan PSN sebanyak 31 orang $(37,8 \%)$. Sedangkan pada responden yang tidak bekerja melakukan praktik pemberantasan sarang nyamuk sebanyak 8 orang $(9,7 \%)$ dan tidak melakukan sebanyak $4(4,8 \%)$. Hasil uji statistik dengan menggunakan chisquare, diperoleh hasil $p$ value 0,527. Karena $\mathrm{P}$ value <0,01 maka Ha ditolak maka tidak ada hubungan antara pekerjaan ibu terhadap praktik PSN di kelurahan desa Tanjung Rejo Sunggal. Menurut asumsi peneliti ibu-ibu yang bekerja dan melakukan praktik PSN DBD dengan baik lebih banyak. Selain itu membersihkan lingkungan rumah dan menjaga kesehatan anggota keluarga memang merupakan tanggung jawab ibu rumah tangga.

Hasil penelitian ini sejalan dengan penelitian Hardayati yang menyebutkan bahwa tidak terdapat hubungan antara pekerjaan dengan praktik pemberantasan sarang nyamuk. Hasil penelitian ini sejalan dengan penelitian sebelumnya karena terdapat kesamaan desain penelitian. Kenyataan di lapangan menunjukkan responden yang tidak bekerja memiliki praktik PSN DBD kurang baik, karena kesadaran responden akan pentingnya praktik PSN dan bahaya DBD masih kurang. Seharusnya bagi responden yang tidak bekerja, dan memiliki waktu yang luang yang lebih banyak dan dapat digunakan untuk melakukan praktik PSNA DBD, sehingga lingkungan tidak menjadi tempat perkembangbiakan nyamuk.

\section{Hubungan Dukungan Petugas Kesehatan terhadap praktik PSN}

Hasil penelitian menunjukkan dari 82 orang responden mengatakan ada dukungan petugas kesehatantentang PSN sebanyak 52 orang $(63,4 \%)$ yang melakukan praktik PSN sebanyak 38 orang $(54,8 \%)$ dan tidak melakukan praktik PSN sebanyak 7 orang. Masyarakat yang mengatakan tidak ada dukungan petugas kesehatan tentang PSN sebanyak 30 orang $(36,9 \%)$ yang melakukan praktik PSN sebanyak 2 orang $(2,4 \%)$ dan tidak melakukan praktik PSN sebanyak 28 orang.

Hasil uji statistik dengan menggunakan chi-square, diperoleh hasil $p$ value 0,527 . Karena $\mathrm{P}$ value $<0,01$ maka Ha diterima maka ada hubungan dukungan petugas kesehatan terhadap praktik PSN di kelurahan desa Tanjung Rejo Sunggal. Ada rangsangan dari luar (dukungan petugas kesehatan) akan mempengaruhi perubahan perilaku seseorang. Penyuluhan yang diberikan oleh petugas kesehatandalam pemberantasan sarang nyamuk.

Hasil penelitian ini sejalan dengan yang dilakukan oleh Nuryanti yang menyebutkan bahwa terdapat hubungan antara peran petugas kesehatan dengan praktik PSN DBD oleh masyarakat. sMenurut asumsi peneliti dukungan petugas kesehatan bisa didapatkan dengam mengajak masyarakat melakukan kegiatan gotong royong, melakukan penyuluhan keehatan kepada masyarakat tentang pentingnya pemeliharaan lingkungan dengan PSN DBD. Dengan dilakukannya penyuluhan kesehatan dapat meningkatkan pengetahuan ibu dan masyarakat lainnya.

\section{Hubungan Dukungan Keluarga terhadap praktik PSN}

Hasil penelitian menunjukkan dari 82 orang yang mengatakan ada dukungan keluarga tentang PSN sebanyak 44 orang $(53,6 \%)$ yang melakukan praktik PSN 
sebanyak 38 orang $(46,3 \%)$ dan tidak melakukan praktik PSN sebanyak 6 orang $(7,3 \%)$. Masyarakat yang mengatakan tidak ada dukungan keluarga tentang PSN sebanyak 38 orang $(46,3 \%)$ yang melakukan praktik PSN sebanyak 9 orang $(10,9 \%)$ dan tidak melakukan praktik PSN sebanyak 29 orang (35,3\%). Hasil uji statistik dengan menggunakan chi-square, diperoleh hasil $p$ value 0,527. Karena $p$ value <0,01 maka Ha diterima maka ada hubungan dukungan keluarga terhadap praktik PSN di kelurahan desa Tanjung Rejo Sunggal.

Keluarga adalah lingkungan dalam kehidupan anak oleh karena itu keluarga ikut member andil dalam membentuk perkembangan fisik dan kepribadian anak, teritama ibu yang sejak kecil mengasuhnya. Hal tersebut sesuai dengan penelitian Satoto, bahwa lingkungan luar yang sangat berpengaruh terhadap tumbuh kembang anak adalah lingkungan asuhan termausk interaksi anak dan stimulasi keluarga (Nuryanti, 2012).

Menurut asumsi peneliti peran dukungan keluarga yang bisa membantu pencegahan penyakit DBD adalah ibu. Karena ibu mampu melakukan kegiatan PSN baik dirumah maupun disekitar lingkungan rumah yaitu dengan melakukan $3 \mathrm{M}$ (menguras, mengubur barang-barang bekas, dan menutup tempet penampungan air)

\section{Hubungan Sarana dan Prasarana terhadap praktik PSN}

Hasil penelitian menunjukkan dari 82 orang responden yang mengatakan tersedia sarana prasarana PSN sebanyak 54 orang (100\%) yang melakukan praktik Praktik PSN sebanyak 44 orang $(81,5 \%)$ dan tidak melakukan praktik PSN sebanyak 10 orang $(18,5 \%)$. Pada masyarakat yang mengatakan tidak tersedia sarana prasarana PSN sebanyak 28 orang, yang melakukan PSN 4 orang (14,3\%), dan tidak melakukan praktik PSN 24 orang
$(85,7 \%)$. Hasil uji statistik dengan menggunakan chi-square diperoleh hasil $p$ value $<0,000$ karena $\mathrm{p}$ value $<0,01$ maka Ha diterima maka ada hubungan antara sarana prasarana terhadap praktik PSN di kelurahan Tanjung Rejo Medan Sunggal.

Hasil ini sesuai dengan Lawrence Green yang mengungkapkan bahwa sarana prasarana merupakan faktor yang mendukung masyarakat untuk berbuat atau berperilaku baik dalam kesehatan, artinya dengan adanya faktor pendukung tersebut (sarana prasarana) maka masyarakat akan melakukan kegiatan yang nyata dalam pemberantasan nyamuk Aedes aegypti (Hardayanti, 2015).

Menurut asumsi peneliti dari pengamatan peneliti dilapangan sarana dan prasarana yang dikeluhkan masyarakat adalah tidak adanya lahan untuk mengubur barang-barang bekas karena perumahan yang sangat padat sehingga lahan untuk mengubur barang-barang bekas tersebut tidak ada sehingga banyak barang-barang bekas seperti kaleng, botol bertumpukan di belakang rumah dan itu sumber sarang nyamuk Aedes aegypti. Oleh karena itu yang paling efektif adalah pencegahan dengan menguras, menutup dan pemberian bubuk abate di tempat penampungan air masyarakat.

\section{Faktor-faktor yang mempengaruhi praktik pemberantasan Sarang nyamuk}

Dari hasil uji analisis multivariate dengan menggunakan uji logistic berganda diperoleh hasil bahwa dari enam variabel yang termasuk dalam analisis, empat diantaranya yaitu variabel pengetahuan, sikap, dukungan petugas kesehatan dan dukungan keluarga mempunyai p-value $<0.01$. Semua faktor yang berhubungan dengan xy dalam uji tersebut diketahui bahwa faktor pengkajian yang lebih tinggi tingkat pengaruhnya adalah pengetahuan.

Pengetahuan masyarakat akan pentingnya pemberantasan sarang nyamuk akan mendorong masyarakat untuk melakukan 
PSN DBD, masih banyak masyarakat masyarakat yang kurang pengetahuannya tentang PSN-DBD ini. Tanggung jawab dari petugas kesehatan adalah memberikan penyuluhan iyang intensif mengingat bahaya yang diakibatkan oleh penyakit demam berdarah ini bisa mengakibatkan kematian. petugas kesehatan harus menyadari bahwa pendidikan masyarakat yang rendah berpengaruh terhadap pemahaman mereka terhadap suatu informasi yang diperolehnya, oleh karena itu pendekatan yang edukatif dan kooperatif bersama aparat kelurahan setempat harus dilakukan (Hardayanti, 2015).

Pengalaman peneliti dilapangan adalah hal yang sangat berharga dimana masyarakat masih banyak yang menolak bila dilakukan pemeriksaan jentik-jentik nyamuk dirumah dengan alas an merasa terganggu dan kurangnya kooperatif masyarakat menjadi pertanyaan besar peneliti dan dengan koordinasi melalui aparat setempat akhirnya peneliti mendapatkan informasi bahwa sebagian besar masyarakat mau didatangi rumahnya kalau memberikan buah tangan seperti sembako, dan lainnya. Hal ini terjadi karena kurangnya pengetahuan masyarakat tentang PSN DBD, sebagian masyarakat masih berfikir bahwa pemeriksaan jentik nyamuk itu tidak memberikan keuntungan secara materi tetapi halnya mereka tidak menyadari kegiatan ini sangat bermanfaat untuk kepentingan kesehatan keluarga.

\section{KESIMPULAN}

Berdasarkan hasil penelitian faktorfaktor yang mempengaruhi prkatik pemberantasan sarang nyamuk di desa Tanjung Rejo Medan Sunggal dapat di simpulkan ada pengaruh antara pengetahuan, sikap, pendidikan, dukungan petugas kesehatan, dukungan keluarga, sarana prasarana dengan praktik pemberantasan sarang nyamuk desa Tanjung Rejo Medan Sunggal.

\section{UCAPAN TERIMAKASIH}

Penulis mengucapkan terimakasih kepada: Kepala Puskesmas wilayah kerja Medan Sunggal yang telah memberikan bantuan selama melaksanakan pengambilan penelitian ini, Kepala Lingkungan dan seluruh masyarakat Lingkungan Tanjung Rejo Kecamatan Medan Sunggal, Kolonel (Purn) dr.Tjahaya Indra Utama, Sp.An selaku Ketua Yayasan Wahana Bhakti Karya Husada Perwakilan Daerah Sumut dan Sumbar, Suharto, S.KM., M.Kes selaku Direktur Akademi Keperawatan Kesdam I/BB Medan

\section{DAFTAR PUSTAKA}

Adi, A. A. (2015). Hubungan lingkungan fisik dan tindakan PSN dengan penyakit demam berdarah dengue di wilayah buffer Kantor Kesehatan Pelabuhan Kelas II Samarinda. Jurnal Ilmiah Manuntung.

Ayuningtyas, E. D. (2013). Perbedaan Keberadaan Jentik Aedes aegypti Berdasarkan Karakteristik Kontainer di Daerah Endemis Demam Berdarah Dengue (Studi Kasus di Kelurahan Bangetayu Wetan Kotas Semarang Tahun 2013). Skripsi. Semarang: Fakultas Ilmu Keolahragaan, Universitas Negeri Semarang. Http://lib.unnes. ac.id/17922/2/6411409122.pdf

Dewi Nila P. (2015). Faktor-Faktor Yang Berhubungan Dengan Praktik Pemberantasan Sarang Nyamuk Demam Berdarah Dengue (Psn Dbd) Keluarga Di Kelurahan Mulyoharjo Kecamatan Jepara Kabupaten Jepara. Skripsi jurusan ilmu Kesehatan masyarakat Universitas Negeri Semarang

Faldy, R., Kaunang, W. P. J., \& Pandelaki, A. J. 2015. Pemetaan kasus demam berdarah dengue di Kabupaten Minahasa Utara. Jurnal Kedokteran Komunitas dan Tropik. 
Hardayanti (2015) Faktor-faktor yang berhubungan dengan tindakan Kepala keluarga dalam upaya pencegahan penyakit Demam Berdarah Dengue di desa Gondang Tani wilayah kerja Puskesmas Gombong II Kabupaten Sragen. Unversitas Muhammadiyah Surakarta.

Hodijah, D. N., Prasetyowati, H. and Marina, R. (2015) 'Tempat Perkembangbiakan Aedes Spp. Sebagai Penular Virus Dengue Pada Berbagai Tempat Di Kota Sukabumi', Jurnal Ekologi Kesehatan, 14(1).

Kemenkes RI (2013) Pedoman Pengendalian Penyakit Demam Berdarah Dengue di Indonesia. Jakarta: Ditjen Pengendalian Penyakit dan Penyehatan Lingkungan.

Kemenkes RI. (2019). Profil Kesehatan Indonesia Tahun 2019. Jakarta: Kemenkes RI

Kemenkes (2020) data kasus terbaru DBD di Indonesia. https://sehatnegeriku.kemkes.go.id/b aca/umum/20201203/2335899/datakasus-terbaru-dbd-indonesia/

Manalu, H.S.P., \& Munif, A. (2016).Pengetahuan dan Perilaku Masyarakat dalam Pencegahan Demam Berdarah Dengue di Provinsi Jawa Barat dan Kalimantan Barat. Aspirator, 8(2), 69-76.

Mohammad.(2015).Hubungan

sosiodemografi dan lingkungan dengan kejadian penyakit Demam berdarah di kecamatan bukit raya kota Pekanbaru. Universitas Sumatera Utara

Notoatmodjo, S. (2014). Metodologi Penelitian Kesehatan. Jakarta: Rineka Cipta

Notoatmodjo, S. (2014). Promosi Kesehatan dan Perilaku
Kesehatan. Edisi revisi. Jakarta: Rineka Cipta

Nurhayati. (2014). Faktor-faktor yang berpengaruh terhadap kejadian DBD di kota Makassar. Jurnal Kedokteran Yarsi.

Nuryanti.(2012). Hubungan faktor penjamu (Host) pada kelompok usia Produktif dengan kejadian Demam berdarah (Studi di wilayah kerja Puskesmas Gombong II Kabupaten Kebumen). Universitas Dipenegoro.

Pandaibesi, R. (2017). Hubungan Pengetahuan, Sikap, dan Perilaku Masyarakat dengan Kejadian Demam Berdarah di Kecamatan Medan Sunggal. Skripsi. Medan: Universitas Sumatra Utara.

Pangaribuan, R., Pangaribuan, N. (2020).Media Pembelajaran Promosi Kesehatan., Bengkulu. ElMarkazi

Riyanto, A. (2011). Aplikasi Metodologi Penelitian Kesehatan. Nuha Medika: Yogyakarta.

Rismawati \& Nurmala. (2015). Analisis Asosiasi Pemberantasan Sarang Nyamuk Terhadap Penurunan Insiden Demam Berdarah Dengue Di Wilayah Kerja Puskesmas Tenggilis Surabaya. Vo. 11. No. 1. Surabaya : FK Unair

Supriyanto. (2011). Hubungan atara Pengetahuan, Sikap, Praktek Keluarga tentang Pemberantasan Sarang Nyamuk (PSN) dengan Kejadian Demam Berdarah Dengue di Wilayah Kerja Puskesmas Tlogosari Wetan Kota Semarang. [Artikel Karya Tulis Ilmiah] Semarang: Universitas Diponegoro. 